\title{
Built Heritage Repurposing and Communities Engagement: Symbiosis, Enabling Processes, Key Challenges
}

\author{
Serena Viola
}

check for updates

Citation: Viola, S. Built Heritage Repurposing and Communities Engagement: Symbiosis, Enabling Processes, Key Challenges. Sustainability 2022, 14, 2320 https://doi.org/10.3390/ su14042320

Academic Editor: Asterios Bakolas

Received: 3 January 2022

Accepted: 11 February 2022

Published: 18 February 2022

Publisher's Note: MDPI stays neutral with regard to jurisdictional claims in published maps and institutional affiliations.

Copyright: (C) 2022 by the author. Licensee MDPI, Basel, Switzerland. This article is an open access article distributed under the terms and conditions of the Creative Commons Attribution (CC BY) license (https:// creativecommons.org/licenses/by/ $4.0 /)$.
DiARC, Department of Architecture, Università degli Studi di Napoli Federico II, 80100 Napoli, Italy; serena.viola@unina.it; Tel.: +39-081-2538419

\begin{abstract}
The paper debates the results achieved in the Sanità district of Naples within the funded research project Play_ACT by the Department of Architecture, University of Naples Federico II. The research investigates community engagement processes in built heritage design for repurposing. Based on mixed deductive and inductive approach, this paper frames the built heritage in the following ways: (a) a record of historical development and way of life, a linking capital between community and context; (b) the enabler of community engagement, representative of creative skills and work of humankind; and (c) a driving force for growth. The paper analyses several community-driven repurposing practices experienced within European programs. Supported by the ISO 37104: 2019 and UNI 11151-1: 2005 standards, the paper focuses on the replicability of community engagement in built heritage repurposing processes, outlining the commonalities in terms of strategies, actions, and actors involved in: (1) discovery; (2) negotiation; and (3) sharing. Focusing on the Sanità district of Naples, the research experiences the sustainability of community-led repurposing, observing long-lasting spillover effects on the physical, economic, cultural, and social subsystems. Finally, with the support of a heritage case study, Cristallini 73, future key challenges for a durable and inclusive community engagement are outlined: A activation of collaborative networks; B promotion of inclusive dynamics of long-life learning; and $\mathrm{C}$ creation of cultural and creative industries.
\end{abstract}

Keywords: built heritage; repurposing; community-led; process; system; replicability; ISO 37104: 2019; UNI 11151: 2005; Sanità district

\section{Introduction}

A broad and lasting local development marks contexts where communities are involved in built heritage maintenance, reuse, and refurbishment [1]. Built heritage repurposing is a privileged field of commitment, in which communities give operativity to the idea of shared engagement towards nonrenewable resources [2]. In response to an almost instinctual desire to compensate for globalised world unsustainability, the centrality recognised to communities strongly affects procedures and methods for buildings and urban settlements that lost their original purposes while retaining their material and constructive features [3]. Built heritage repurposing can modify configurations without altering the original conceptions and improve sites' attractiveness and jobs, impacting processes and product innovations [4]. A bottom-up, community-driven perspective increasingly connotes the design approaches. Knowledge-intensive, based on the perceived identity and collective creativity, the community-centred vision aims at extending the life cycle, driving built settlements' transition towards prosperity [5].

The paper resumes and brings forwards the results achieved in the Sanità district of Naples within the funded research project conducted by the Department of Architecture of the University of Naples Federico II (DiARC) "Playgrounds and Art for Communities in Transition: care pact for cities" (Call FRA Federico II, 2021-2023).

Over the last decade, the programmatic commitment put in place by international heritage organisations and the European Community redesigned the coordinates of a 
coevolutionary approach for built heritage repurposing, renewing the symbiosis between the material and immaterial dimensions of heritage. It came about with the support of a theoretical effort and several design experiences; preserving values and adapting spaces for new uses cross communities commitments.

The paper focuses on the enabling processes that mark community engagement in design for repurposing. The transition from an occasional and discontinuous conception of stakeholders involvement to one that makes the repurposing process replicable is the novelty of this paper. Local authorities, entrepreneurship, higher education, and citizens are the fundamental actors able to turn built heritage into a resource [6].

Comparing the community-led strategies and actions tested in the framework of European funding programs with the process realised in the Sanità district of Naples, the paper questions the challenges still to be faced for effective, long-lasting, and inclusive engagements [7]. The hypothesis is that iterative community-led processes restore technical awareness, practical ability, and creative intuition to local actors and can increase sustainability on a cultural basis with the support of new enterprises.

The paper is articulated as follows: first, a brief background is given on the international framework for heritage preservation and community engagement, with the methodology description (Section 2); then, there are the critical reviews of commonalities between heritage repurposing approaches in some EU programs and a description of the processes activated in the Sanità district of Naples (Section 3). Finally, the hypothesis is validated in a heritage case study, Cristallini 73, outlining future key challenges for community engagement (Section 4).

\section{Materials and Methods}

\subsection{Research Background: The International Framework}

Reactivating the symbiosis between built assets [8] and communities [9] is a horizontal commitment for built heritage preservation and transmission today.

There is no standard definition of built heritage characters in the EU member states. While age is not a common criterion, two main elements are commonly stressed across the different national interpretations:

- Buildings and assets are an essential record of historical development and way of life;

- Buildings and assets represent humankind's creative skills and work (artistic, architectural, technical, technological) [10].

The term heritage has been used for centuries with a meaning of sacredness [11]. It gradually included more extensive areas, from individual assets of exceptional value (monuments, sites, ensembles) to cultural landscapes [12,13]. The term referred to the material and immaterial assets, skills, practices, knowledge, and expressions of human creativity. The UNESCO World Heritage Convention identifies the tangible cultural heritage, apart from monuments, in the following:

- Groups of separate or connected buildings which, because of their architecture, homogeneity, or place in the landscape, are of outstanding universal value from the point of view of history, art or science;

- Sites, works of man or the combined results of nature and man, and areas including archaeological sites of outstanding universal value from the historical, aesthetic, ethnological, or anthropological point of view [12].

An expanded awareness about the need to share responsibilities towards heritage through values matured in contexts and handed down over time profoundly renews the action of expert knowledge and communities [14]. With diversified areas of interest and expertise, international organisations - first of all, UNESCO and ICOMOS — have launched a process of reviewing the principles, methods, and procedures of enhancement, protection, and management over the last few years. A priority role in procedural innovation for the transmission of assets is assumed by the institutions of the European Union-Commission, Parliament and Council of Europe. Although cultural policy and heritage care have fallen 
under the responsibility of the Member States since the founding of the Council of Europe in 1949, among the EU's priority objectives is the commitment to respect "the richness of cultural and linguistic diversity and [to supervise] the safeguarding and development of the European cultural heritage" [15]. Article 6 of the Treaty on the Functioning of the European Union [16] establishes that in the field of culture, the Union has the competence to carry out actions aimed at supporting, coordinating, or complementing the action of the Member States. By keeping culture and heritage together, the recomposition of a shared European specificity supports policies and plans for economic growth and social cohesion. Since 2000, this commitment has been made explicit in the motto of the European Union, "united in diversity".

Following the commitments made in Lisbon [17], the framework of cultural heritage actions is reviewed, focusing on the consequences determined in areas including regional and urban development, social cohesion, environment, tourism, the digital agenda, research, and innovation.

Design for repurposing has been defined as the process for individual buildings and assets that lost their original functionality while retaining their material and constructive features [18]. Maintenance, adaptive reuse, and refurbishment are design solutions that allow reorganising configurations and layouts [19] without altering the original structural conceptions [5].

The slow recognition of heritage communities' role, initiated with the Framework Convention on the Value of Cultural Heritage for Society [9] and the processes for ratification in the various countries (Italy, 2020), marks a paradigm shift in assets repurposing.

The international commitment seeks the symbiosis between sites and communities, working on the embedded values and transformative processes. It promotes the idea of built heritage as follows (Figure 1):

- Record of historical development and way of life, linking capital between community and context [9];

- Representative of creative skills and work of humankind, enabler of community engagement and empowerment [8];

- $\quad$ Driving force for growth [20].

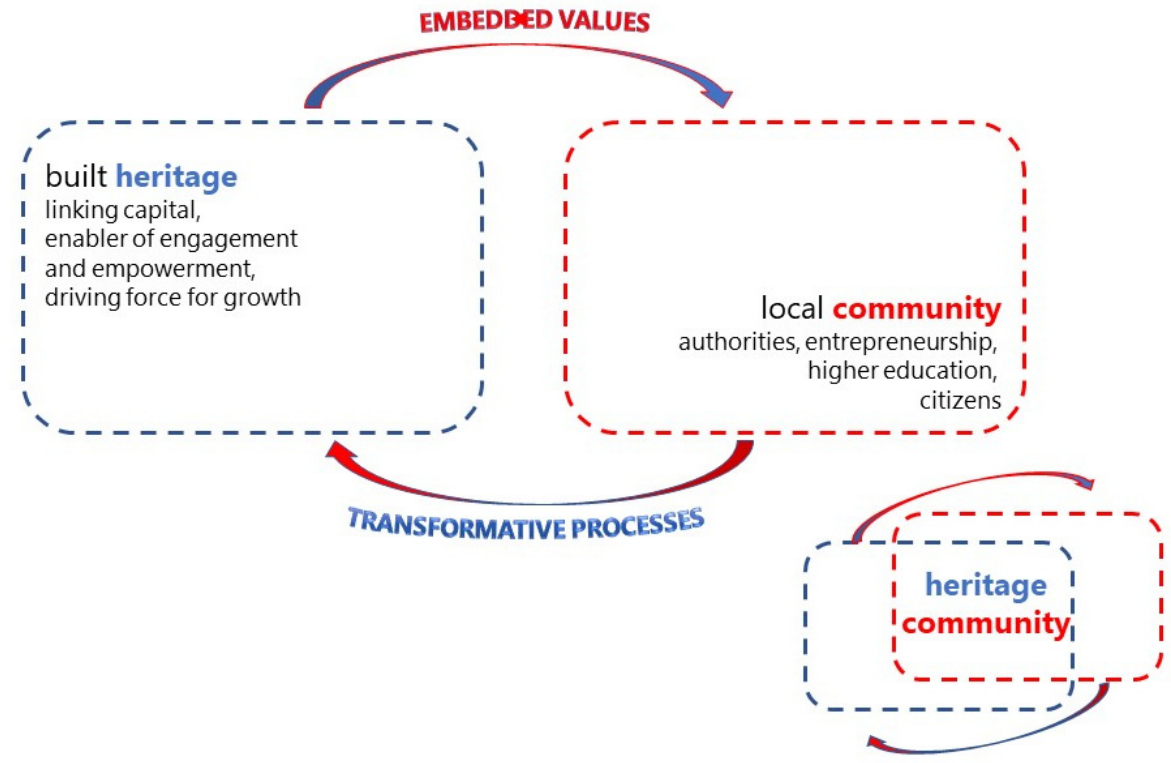

Figure 1. The relationships between heritage and community.

a. The Faro Convention highlights the relationship between collaboration skills, protection of contexts, community empowerment and development [9]. The Convention deals with heritage as an object of individual rights that give it meaning. Heritage is treated both as a "source" and as a "resource" for exercising freedoms. Heritage is 
treated as a source of prosperity and a resource for exercising freedoms. The Convention answers to the desire of the Committee of Ministers to provide a framework of reference for heritage policies in the context of rights and responsibilities, providing the basis for the use of heritage as cultural capital. The Framework Convention admits that the value of cultural heritage does not reside in the objects and places themselves but their meanings and uses. Therefore, identifying and empowering individuals' and communities' skills is key to harnessing cultural heritage's potential.

b. The UNESCO Recommendation on the historic urban landscape subordinates the future of humanity to culture, promoting the rebalancing of growth and quality of life through design [8]. In the historical layering of values, traditions, and experiences, settlements promote economic development and social cohesion. Furthermore, the Recommendation introduces the need to encourage cooperation between expert knowledge and the community to frame the conservation strategies within the broader objectives of global sustainable development.

c. The EU Council under the Italian Presidency in 2014 strengthened the role attributed to asset productivity. It opened up new opportunities to community-based income through refurbishment, adaptive reuse, and maintenance [21]. During the semester of the Italian Presidency, the Council of Ministers of the European Union, in the Conclusions on participatory governance of cultural heritage, promotes subsidiarity in managing cultural resources. Furthermore, by introducing multi-stakeholder and multilevel governance, the Council identifies civic participation as the opportunity to relaunch territories, innovating and revitalising them [22].

With the European Framework for Action on Cultural Heritage [23], the European Commission identifies cultural heritage as the main competitive asset of the Union and the lever for economic and social development. This document calls for an integrated approach to fully use the potential of cultural heritage for economic growth and social cohesion. However, the cut in public investments, the development of social inequalities, globalisation, and the trafficking of cultural goods require the revision of management and business models for built heritage, which are anchored to nineteenth-century visions and policies. Exploring the potential for sustainability and development inherent in collective governance based on community empowerment was an objective already introduced by the European Commission's Directorate-General for Education and Culture (DG EAC) through the work plan for culture 2015-2018 [22]. Heritage sustainability was linked to the attitude to produce benefits for communities [24]. The broader benefits of cultural heritage are further emphasised in the report Getting Cultural Heritage to Work for Europe developed by the Horizon 2020 Expert Group on Cultural Heritage [25] and the Cultural Heritage Counts for Europe report [26]. Furthermore, the European Strategy for the 21st century, approved by the Council of Europe [27], outlines the renewed framework of the contributions that social innovations can bring to society, the economy, and international relations in the short future. Furthermore, due to the hiring block, the lack of turnover of the personnel involved in the management and care of assets requires the empowerment of professional skills to transfer to young professionals of the experience gained in the field [28].

\subsection{Methodology}

The methodology is designed starting by analysing the international heritage literature on communities engagement in buildings repurposing, examining the works that record the shift from expert-led authoritarian procedures towards more inclusive and participative practices $[29,30]$.

The paper resumes and brings forwards the results already achieved within the project Creative Europe 2018, Artists in Architecture, Reactivating modern European houses (call EACEA 32/2017 and EACEA 35/2017; project manager: Serena Viola), by the Department of Architecture of the University of Naples Federico II (DiARC). In continuity with that experience, today, the research project Play_ACT experiments in the Sanità district of 
Naples, an interesting and multifaceted community-led repurposing "Playgrounds and Art for Communities in Transition: care pact for cities" (Call FRA Federico II, 2021-2023).

According to the management system standard proposed by the ISO 37104 [31], the methodology is based on a mixed deductive and inductive approach that offers practical guidance to processes involving communities in all types of human settlements that are holistic, inclusive, and sustainable. This standard emphasises the role of communities in achieving quality objectives and traces the ideals of sustainability to long-term goals expressed in the light of the United Nations SDGs, in particular n11. The principle that informs this standard is that development requires global strategies and local actions, which differ in context and content, supported by the specific commitment of each community.

A baseline review is built on the contents of the UNI 11151-1:2005 standard [32] to map in the frame of global strategies local actions that see the community as a protagonist of built heritage repurposing, at different scales from the urban settlement to the building system and its technical components. A systemic approach informs the baseline review: decomposing the built heritage into units and components and taking past and present relationships into account. Settlement systems are the result of modifications, which affect places and organisations. Each phenomenon manifests itself conditioned or conditioning others, and interacting with them. According to careful approaches, the systems theory makes it possible to observe the built environment in a holistic key: examining the complexity of the relationships between entities, analysing their performances, hierarchies, and evolutionary processes. The baseline review returns a procedural framework in which investors, experts, local administrators, and inhabitants are engaged within the phases of knowledge, scheduling, design, execution, and management, with actions that can be resumed as (1) Discovery, (2) Negotiation, and (3) Sharing.

Supported by the ISO 37104: 2019 [31] and UNI 11151-1: 2005 [32] standards, the paper describes the community involvement in the case study Cristallini 73 and outlines the four subsystems where spillover effects have been registered: physical, social, economic, and cultural. Key challenges for future engagements result from impacts observation: A collaborative networks; B inclusive dynamics of long-life learning; and C cultural and creative industries promotion.

\section{Turning Built Heritage into a Resource}

\subsection{Commonalities between Community-Led Heritage Repurposing Experiences}

Studies on the contribution that participation can offer to the sustainable development of communities have appeared in international heritage literature since the 1980s, with research on the everyday use of heritage in contemporary society [33,34]. The idea that heritage is not an object but a process is fundamental for renewing the approaches. Objects and sites are "vehicles for the transmission of ideas in the service of a wider range of contemporary social needs" [35]. Assuming that heritage exists because people attach value to it [36], scholars observe the way people are involved in the transformative processes and work on approaches to connect people with the embedded values [37-39].

Over the last decade, researchers stated the indispensability of a high level of community participation within the whole process of built heritage repurposing from knowledge acquiring to negotiating needs definition or solutions sharing [40]. The dynamism and diversity of initiatives push researchers to observe best practices with the support of quantitative and qualitative analyses to understand built heritage's potential to stimulate local development and innovation [41,42]. Scientific research studies deal with the following: community identification [43]; active participatory methods analysis-to raise awareness and build capacities in local communities; and community participation approaches-to integrate cultural heritage management in sustainable urban development [44,45].

Communities' engagement processes pursue the rapprochement of people and contexts with the support of diversified actions: from knowledge acquisition to the negotiation of design approaches, alliances between institutions, and sharing of skills. In addition, factors internal and external to the communities condition the methods and degree of 
involvement: the cultural context, public-private partnerships, and synergies between managers and users of capital resources [46].

The Play_ACT research is part of this segment of studies with a mapping of communityled repurposing experiences in European countries. Stemming from the strategic agendas, funding programs, and initiatives implemented across EU regions, a baseline review of best practices is initiated starting from the decomposition of the built heritage process introduced by the council regulation UNI 11151-1: 2005 [32]. The standard defines intervening on the already built, as an organised sequence of phases that lead from the clients and users need assessment to their satisfaction, from the evaluation of the existing performances to their maintenance and/or improvement, from identifying other asset values to their confirmation and/or increase.

The baseline review feeds on data drawn from various sources: international literature, documented investments promoted by public-private partnerships capable of contributing to the implementation of Agenda 21 for culture, Creative Europe program (Regulation (EU) No. 1295/2013 of the European Parliament) on the occasion of the European Year of Cultural Heritage 2018, and other European-funded initiatives (e.g., Social Europa funds).

According to the UNI 11151-1: 2005 standard, the baseline, which currently includes over 60 experiences, examines the role of communities in the stages of knowledge, scheduling, design, execution, and management. Three criteria have been adopted to the select best practices in which communities are the pivotal stakeholders: (a) built heritage as a record of historical development and way of life; (b) built heritage as the enabler of community engagement and empowerment; and (c) built heritage as a driving force for growth. Each experience is observed in terms of the following:

- Stakeholders involved, distinguishing between local administrators, investors, entrepreneurs, experts, researchers, artists, artisans, and citizens, also differentiating the age groups;

- Local actions, distinguishing between workshops, field trips, exhibitions, audience engagement, enhanced interaction, crowdsourcing, and capacity building.

The first best practice examined is the Temple Bar district in Dublin. Since the 1990s, it has introduced an innovative management model with community engagement that connotes both the scheduling and execution phases and the creation of an extended network revolving around the City Council. With the support of the Urban Pilot Scheme (1990-1999) and the cultural strategy of the City Council (2010-2017), built heritage repurposing crosses the promotion of cultural activities. The first interventions were funded under the Urban program, with 255 million euros between 1990 and 1999, with a leverage effect on private investments. The process has triggered synergies between 34 local administrations and 150 key stakeholders [47].

At the opposite extreme is the well-known case of the Gallery of Urban Art of Lisbon created in 2008 in the historical neighbourhood of Bairro Alto. The GAU aimed to promote artistic citizenship, raise people's awareness about built heritage qualities, and prevent the emergence of vandal interventions on heritage. The initiative recognised street art as an expression of contemporary culture and activated an intensive dialogue with the artistic community of graffiti and street artists. However, the general public involvement is limited to the knowledge stages, only triggering a management approach based on respect. Despite the quality of the results achieved on an architectural level, this experience shifts reflection on the risks and criticalities of processes in which community engagement fails to activate lasting synergies between places and the people who live there [48]. The initiative projected Lisbon onto the international art scene, promoting the birth of a flood of art galleries. On the cultural and economic level, the experience achieves a significant result with the participation of the GAU as the founder in 2011 of the International Network for Urban Creativity. The commitment to disseminate the methodologies and results achieved, supported by a social media strategy on Facebook, was rewarded with registering Google's everlasting collection of street art (https: / / artsandculture.google.com/partner/galeriade-arte-urbana; accessed on 10 February 2022). The Committee on culture of the world 
organisation of United Cities and Local Governments (UCLG) recognised this project as a good practice implementing Agenda 21 for culture.

The water-powered corn mill in Carlisle repurposing promotes similar processes but with a much more local resonance; the European Council selected it as good practice in Strategy 21. In this experience completed between 2015 and 2019, the community was engaged in knowledge, execution, and management. About 2 million pounds ( 2.4 million euros) were invested in the mill's purchase and refurbishment with local artisans' involvement. The children were the first stakeholders who could reuse the building thanks to the cooperation established by the residents, municipalities, and interest groups with schools and colleges. Returning productivity is the goal pursued with the support of research, integrating the studies for the conservation of the product with the prediction of business feasibility and market tests [49].

During the European Year of Heritage 2018, the Creative Europe program (Regulation (EU) No. 1295/2013 of the European Parliament) supports other practices [50]. Community engagement is backed with a sensitivity refinement towards cultural, constructive, and productive ecological values. This approach connotes our experience within the funded project Artists in Architecture [51]. Widespread, autonomous, and at the same time connected experiments are the result of an explicit commitment to keep together the awareness of places with the need to combat the social, technical, cultural, and financial crisis. In addition, other European-funded initiatives are taken into account within the baseline, at different scales from the landscape one promoted in Nantes to the building one in Bergen, up to the actions put into practice for a technical element of the construction in Malta (Table 1).

Within the observed experiences, participation moves in the range of the following:

- Top-down approaches, local authority-driven, usually by a high-level head of department or equivalent role from the mayor's office;

- Bottom-up approaches, community-led, traditionally led by a coalition from the arts, heritage, and cultural and creative sectors.

The experiences examined are supported by several forms of partnership:

- Management partnerships-when private parts own the built heritage;

- Research partnerships with universities that help train young professionals and develop new practices;

- Supporting partnerships-when the public protection bodies support other organisations through mentoring and advice, providing technical support;

- Partnerships that support the local economy-new alliances between foundations of banking origin and the third sector support the binomial built heritage repurposing, social cohesion;

- Corporate partnerships-based on commercial agreements under which the partner receives a defined set of benefits while the impact of its work grows. 
Table 1. Best practices analysis.

\begin{tabular}{|c|c|c|}
\hline Best Practice, Year, References & Stakeholders & Actions \\
\hline $\begin{array}{c}1990 \\
\text { Dublin } \\
\text { Temple Bar district } \\
\text { https: / quaysdublin.ie/temple-bar-history/ } \\
\text { (accessed on 10 February 2022) }\end{array}$ & $\begin{array}{c}\text { Dublin City Council, Artistic and cultural } \\
\text { associations, Creative businesses, } \\
\text { Gallery for visual artists, } \\
\text { Cultural centre dedicated to educating } \\
\text { children across artistic fields, } \\
\text { The Irish Film Institute }\end{array}$ & $\begin{array}{c}\text { Knowledge: embedded values and } \\
\text { functional-technological performances } \\
\text { discovery; } \\
\text { Scheduling: needs and requirements } \\
\text { negotiation; } \\
\text { Management: cooperation between cultural } \\
\text { institutions and creative businesses. }\end{array}$ \\
\hline $\begin{array}{c}2008 \\
\text { Lisbon } \\
\text { Urban Art Gallery } \\
\text { http://gau.cm-lisboa.pt/en/gau.html } \\
\text { (accessed on 10 February 2022) }\end{array}$ & $\begin{array}{c}\text { Lisbon's Department of Cultural } \\
\text { Heritage (DPC) } \\
\text { Artists, Citizens }\end{array}$ & $\begin{array}{c}\text { Knowledge: discovery through artistic } \\
\text { production of the embedded values in built } \\
\text { heritage; } \\
\text { Execution: negotiation of artistic intervention in } \\
\text { critical neighbourhoods; } \\
\text { Management: capacity building for cultural and } \\
\text { creative operators; new business models and } \\
\text { digitisation sharing. }\end{array}$ \\
\hline $\begin{array}{c}2013 \\
\text { Corner Teateret Bergen } \\
\text { Marineholmen } \\
\text { https:/ / www.cornerteateret.no/ } \\
\text { https://www.cornerteateret.no/ } \\
\text { https://www.cornerteateret.no/ } \\
\text { (accessed on 10 February 2022) }\end{array}$ & $\begin{array}{c}\text { Norwegian Arts } \\
\text { Council, Bergen City Council; private } \\
\text { sponsors, Paal Kahrs architecture studio, GC } \\
\text { Rieber shipbuilding } \\
\text { company, Theatre organisations Vestlandske } \\
\text { Teatersenter } \\
\text { and Proscen, Citizens }\end{array}$ & $\begin{array}{c}\text { Knowledge: discovery of dismissed buildings; } \\
\text { Execution: compatibility negotiation of } \\
\text { technologies for dismissed industrial } \\
\text { buildings; } \\
\text { Management: capacity building for cultural and } \\
\text { creative operators. }\end{array}$ \\
\hline $\begin{array}{c}\text { 2015-2019 } \\
\text { Carlisle, } \\
\text { UK } \\
\text { https:/ / www.warwickbridgecornmill.co.uk } \\
\text { (accessed on 10 February 2022) }\end{array}$ & $\begin{array}{l}\text { Local administrators, Investors, Researchers, } \\
\text { Craftsmen, Citizens }\end{array}$ & $\begin{array}{l}\text { Knowledge: discovery of past productive } \\
\text { processes and products; } \\
\text { Execution: skills improvement in response to } \\
\text { the production need. }\end{array}$ \\
\hline $\begin{array}{c}2006 \\
\text { in progress } \\
\text { Malta } \\
\text { https: / / www.pa.org.mt/en/news-details / } \\
\text { architectural-icon-the-traditional-maltese- } \\
\text { balcony } \\
\text { (accessed on 10 February 2022) }\end{array}$ & $\begin{array}{c}\text { Maltese local authorities, Buildings' owners, } \\
\text { Companies in the construction sector, } \\
\text { Artisans, Artisans }\end{array}$ & $\begin{array}{l}\text { Execution: negotiation of maintenance practices } \\
\text { for the closed wooden balconies; experiences; } \\
\text { Management: lifelong learning and knowledge } \\
\text { sharing. }\end{array}$ \\
\hline $\begin{array}{c}2007 \\
\text { in progress Nantes } \\
\text { https://www.nantes-tourisme.com/en/ } \\
\text { estuaire-trail } \\
\text { (accessed on 10 February 2022) }\end{array}$ & $\begin{array}{l}\text { Local administration, } \\
\text { Cultural mediators, } \\
\text { Artists, Architects, } \\
\text { Citizens }\end{array}$ & $\begin{array}{l}\text { Knowledge: discovery of the coordinates of a } \\
\text { modern civilisation subject to erosion and } \\
\text { colonisation; } \\
\text { Management: cooperation between cultural } \\
\text { institutions and creative businesses for an } \\
\text { innovative and inclusive heritage } \\
\text { enhancement through artistic production }\end{array}$ \\
\hline $\begin{array}{c}2018 \\
2019 \\
\text { Artists in } \\
\text { Architecture } \\
\text { https://miesbcn.com/project/artists-in- } \\
\text { architecture-re-activating-modern-european- } \\
\text { houses/ } \\
\text { (accessed on 10 February 2022) }\end{array}$ & $\begin{array}{l}\text { Local administration, } \\
\text { Cultural mediators, } \\
\text { Artists, Architects, } \\
\text { Citizens, Tourists }\end{array}$ & $\begin{array}{l}\text { Knowledge: landscape qualities discovery with } \\
\text { the support of events and field trips that } \\
\text { engage visitors and citizens; } \\
\text { Design/Execution: negotiation of collaborative } \\
\text { processes for built heritage maintenance; } \\
\text { Management: citizens and tourists involved in } \\
\text { recognition of the failure processes }\end{array}$ \\
\hline
\end{tabular}

Several strategies drive the community engagement from dialogue and collective memory sharing to productivity returned to the built, material culture hybridised with technological innovation and contemporary art [52]. The baseline review highlights how community engagement is implemented in knowledge, scheduling, design, execution, and management through actions aimed at the following:

1. Discovering. Raising the community awareness and containing the processes of abandonment and decommissioning due to the increase in age to changes in users' lifestyle. Recapturing memory, understanding and sharing transformation processes, and identifying constraints are recurring aspects of the experiences that are attentive to the functions' conservation with auxiliary uses and adaptation through a mix of different 
services [53]. At different scales, the project combines the commitment to realign or increase the environmental and technological unit's performances with the theme of promoting a creative environment, prefiguring scenarios of new entrepreneurship, the attraction of talents, and investments [54].

2. Negotiation of needs and requirements within the scheduling and realisation phases. The achievement of quality objectives is a connotative aim of the experiences put in place [55]. In a rapidly changing world, where built heritage is recognised as commons, quality is the cornerstone of built heritage repurposing. It puts in place integrated responses to the conservation needs and socio-economic development through strategies management based on non-renewability and the non-substitutability of assets. Attention to quality in interventions on heritage has a long history deeply rooted in the disciplinary assumptions of the technological culture of architecture. However, the first drivers of quality are the professionals themselves-craftsmen, architects, engineers - and the owners, institutions, and bodies. Over the last century, the concept of quality refers to interventions on the built heritage that has gone beyond architectural and technical issues at the level of individual buildings, including broader environmental, cultural, social, and economic considerations on sites and their context.

3. Knowledge and procedures, within the execution and management phases, with stakeholders participation in inspections and control, learning skills for maintenance. Sharing is an intentional, ongoing process involving mutual respect, critical reflection, caring, and group participation. As a result, people can more easily access resources and increase control [56].

Discovery, negotiation, and sharing develop relationships:

- $\quad$ Between individual, communities, and places;

- $\quad$ Between past, present, and future;

- $\quad$ Between the local community and external systems.

The practical experiences return a broad framework of spillover effects on physical, social, economic, and cultural subsystems (Figure 2):

- Increase in attractiveness of contexts, ability to attract citizens and investors, to promote a sense of belonging and identity on a cultural basis, encouraging creativity and innovation;

- Conservation and improvement of the environment, protection of ecosystems, reduction of pollution;

- Climate risk reduction and crisis management plans, capital and social capacity development;

- Responsible use of resources, improvement of land use management, reduction of consumption, reuse, recycling of materials, respect for the scarcity of all types of resources (natural, human, and financial), sustainable production, storage and transport;

- Social cohesion, equal access to services, dialogue that enhances diversity, mutuality and shared experiences, roots, a sense of belonging, and social mobility;

- Well-being, access to opportunities, long-life learning, improvement of human capital, healthy environment and liveable city, safety, and trust. 


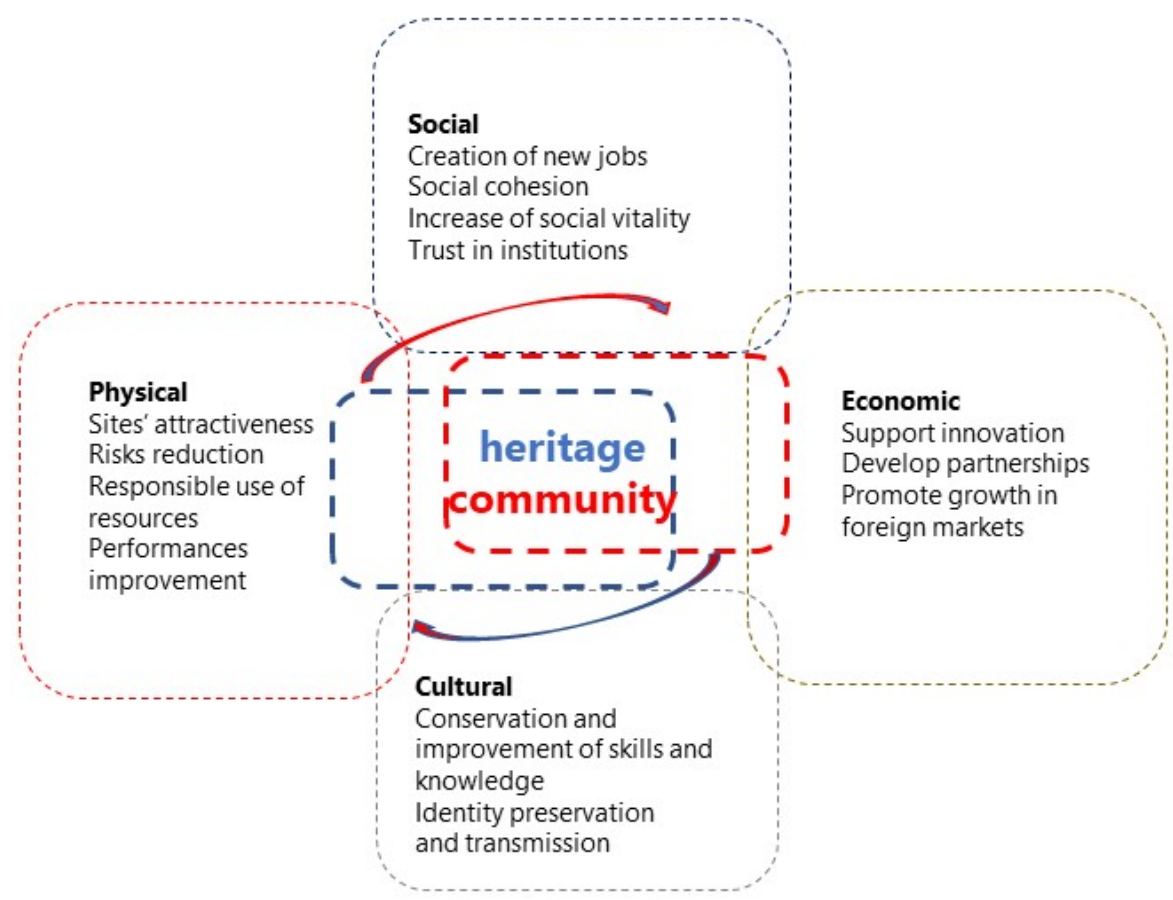

Figure 2. Spillover effects on the physical, economic, cultural, and social subsystems.

\subsection{Case Study: Community-Led Heritage Repurposing in the Sanità District of Naples}

The Sanità district extends over about 2 square kilometres and has a population of up to 32,000 inhabitants. It was a burial place in Roman and Hellenistic times, as witnessed by the discovery of Hellenistic hypogea and Paleochristian San Gennaro e San Gaudioso catacombs [57]. The area was settled in the late 16th century, starting with the construction of the Basilica of Santa Maria della Sanità, becoming the area chosen by Neapolitan nobles and bourgeois for their homes [58].

The Sanità district is perceived as a suburb due to urban planning events that led to its isolation. In the 18th century, its streets became the royal family's route from the city centre to the Capodimonte Royal Palace. In the early 1800s, the construction of the Sanità bridge facilitated access to Capodimonte, causing the isolation of the neighbourhood. Rich in built heritage, it has long been a site dominated by Camorra. Social exclusion is high, as is unemployment or underemployment, despite the historical-cultural potential of the district. Unemployment and undeclared work affect women, with many unemployed mothers (about 66\%). Another peculiarity of the area is the high number of young people aged 0-20 (over $24,000,23 \%$ of the municipal population), many of whom are in educational poverty and at a high risk of early school leaving (with peaks of failure training higher than $30 \%$ ). In recent years, the district has been subjected to migratory pressure due to the low rental costs of the houses (often small dilapidated lands). Regular foreigners represent about $13 \%$ of the total citizen; the main nationalities are Sri Lankan (40\%), Ukrainian (17\%), and Romanian $(6 \%)$, with a high presence of young people and unaccompanied minors.

However, the last few decades have been marked by a change in trend with 6000 square meters of repurposed built heritage, 1500 private donations, and 3.5 million $€$ raised for projects. The San Gennaro Community Foundation was created in 2014 to respond organically to the district's needs. It gathers the entities of the Third Sector that for over 20 years worked to repurpose the built heritage, in particular, the catacombs and the human capital of the neighbourhood [59]. The first step for its creation was the establishment in 2014 of a promoting committee that intended to carry out cultural enhancement in local realities (associations, cooperatives, profit bodies, and free citizens) to raise awareness about the potential of a community foundation. In support of this action, ad hoc events were organised to search for all possible founding partners actively. The benefits of cooperation 
for heritage are evident: in 2008, the catacombs recorded an annual visitor presence of approximately 5000 people, and the number reached 160,000 in 2019.

Since 2015, Santa Maria Maddalena ai Cristallini's heritage site has become the heart of the fragile generations engagement process-both the younger and elderly. It was built at the end of the 1700s as an Asylum House intended to accommodate misguided women who wished to repent. In 1851, the building was completed with a small single-room church, thanks to private donations and charity shows. The complex, renamed today Cristallini 73 , was ceded to the state around 1885 and, because it was not suitable for becoming a prison, assigned to the city. The church bombed in 1943 was restored after World War II, while the complex became a hospice for the disabled in 1952. Finally, at the end of the 1980s, the building returned to the city administration, which intervened with refurbishment and maintenance works, assigning its management to the third Municipality of Naples.

Twenty years of closure and vandalisation affect the performance levels of this built system, spread over three floors, for a total of about 7000 square meters, on three levels, including a roof garden and a terrace. The building develops around three courtyards arranged at different heights: the first, which leads to the complex, is smaller in size, significant in terms of architectural and morphological values with the access staircase; the second is the centre of gravity for the development of spaces, both for accessibility and light and view; the third is marginal both for its position, with many residences overlooking on it, both for the construction events and the life cycle, which have determined an increase in the footfall level due to the spillage of building waste during the construction phases.

The repurposing was completed in 2015, for a total cost of about 12 million euros, and it transformed this building into a welcome hospice for the elderly. However, the third Municipality of Naples, which took over the building, reported since 2015 the impossibility of providing exclusively for the establishment of activities for the elderly due to unsustainable management costs. From this moment, the hypothesis of a mixed repurposing emerges, pending of works for additional 700,000 euros, and providing for its destination to the social policies of the territory, assigning each floor of the building with different functions: territorial education, sports activities for young people, daycare for the elderly, and economic activities with social impact.

The process, supported by maintenance, adaptive reuse, and refurbishment solutions, responds to the symbiosis criteria identified for the best practices selection: (a) the building is a record of historical development and way of life; (b) the building testifies creative skills and work of humankind, (c) the building is a driving force for growth. Three main actors cooperate within this process: the third Municipality makes the structure available and transfers it to the management of the Ministry of the Interior; the Naples Police Headquarters and the Fiamme Oro take over the direction and offer their champions and athletes for sports courses; the San Gennaro Foundation provides utilities (electricity, water, gas), custody, and shifts for educators. Discovering, negotiating, and sharing are the approaches that support the community involvement, becoming aware of the following: the morphological and distributive values of the complex that lies on the hill; the materialthe constructive potential of the bearing structure in yellow tuff masonry; and the use opportunities that repurposing can bring into play due to the diversity of the views and the relative isolation in a particularly dense neighbourhood.

Thanks to a Memorandum of Understanding, part of the building is granted on loan for use to the Fiamme Oro, the sports section of the State Police, which can thus support the young people of the Rione Sanità in the free practice boxing and judo. The Third Sector occupies part of the ground floor with the following:

- Alessandro Pavesi Foundation, which carries out after-school activities aimed at more than seventy children of the neighbourhood, in a quiet and controlled environment, outdoor spaces and a computer room equipped with workstations connected to the network;

- Riva Foundation, with afternoon educational activities to strengthen the training offer. 
In March 2020, with the involvement of the San Gennaro Community Foundation and the associative network of the Rione Sanità, Cristallini 73 became a community home and hosted engaging and inclusive activities. Transforming an abandoned site into commons is the idea that marks the experience. Thus, a social and cultural sports aggregation centre introduces new lymph into one of the peripheral arteries of the Rione Sanità (Figure 3).

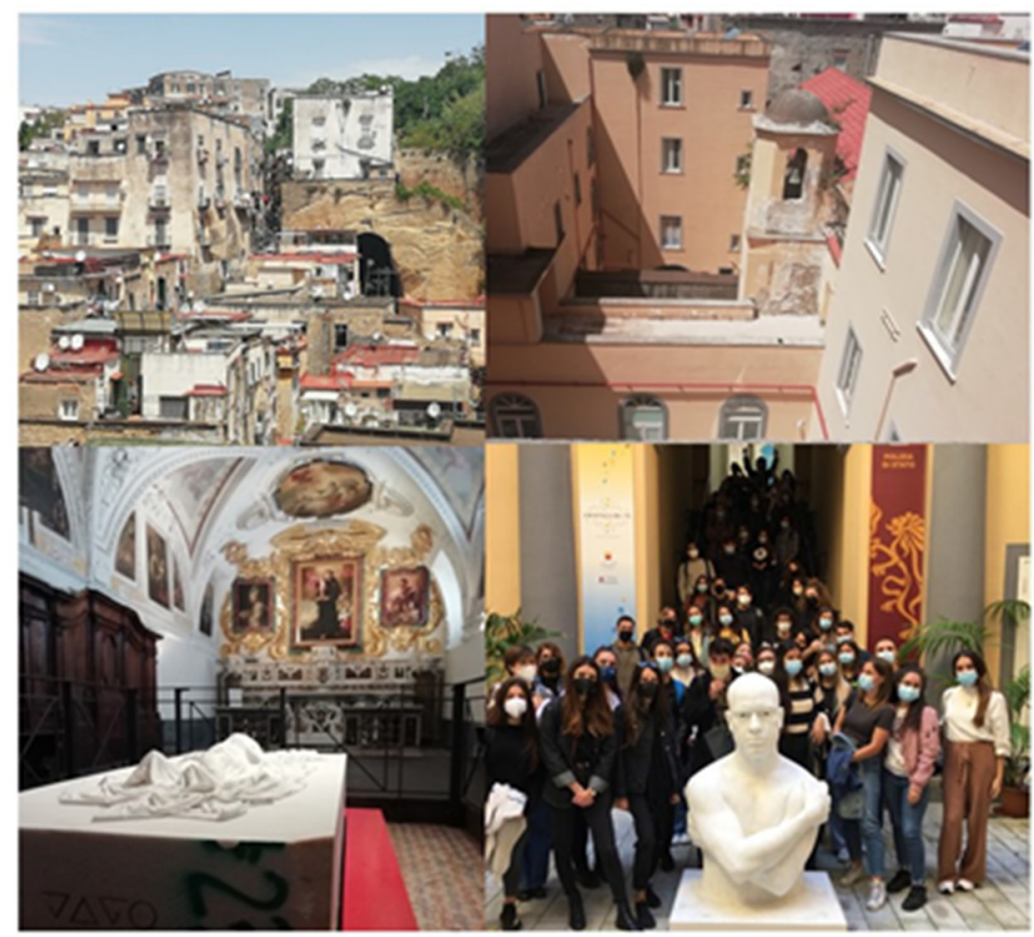

Figure 3. Cristallini 73 in the Sanità district of Naples. Clockwise: view of the neighbourhood, the building, the work of Jago, The veiled son 2019; DiARC students in the first courtyard.

In 2021, two artistic projects were hosted in the Mendicicomio: the first was founded by the University of Naples, Federico II, for an artistic residency aimed at creating a playground in one of the courtyards; the second, Luce ai Cristallini, was financed by Intesa San Paolo with the Fondazione per il Sud. Artistic workshops for 30 children aged 16 to 20 are planned in the Church of Santa Maria Maddalena, with training activities and workshops conducted by artists and witnesses in graphics, cinematography, and photography. At the end of the training courses, the young people involved will fresco the church and the most hidden alleys of the district with the help of internationally renowned muralists. In addition, two info points are realised in the Church of Sant'Aspreno ai Crociferi, at the contemporary artist's studio Jago, and in the Basilica of San Severo fuori le Mura.

\section{Discussion and Emerging Challenges for Future Research}

The concept of community forcefully entered heritage management after the Faro Convention [9]. The term community is adopted as an inclusive construct that includes the following: (1) discovery, with the meaning of exploring and acquiring awareness about the identity of places; (2) negotiating, with the meaning of defining design scenarios and quality standards; and (3) sharing, referred to places, practices, and interests. The concept of heritage community finds applications in variable geometries without reference to ethnicity or other rigid grids. Heritage communities may arise from shared interests in the observed best practices, supported by a geographical foundation linked to a language, religion, values, or past historical links. The limit that connotes them is the commitment discontinuity, which is often related to occasional financing.

The community engagement processes in the Sanità district, born from the intuition on the regenerative potential of beauty and a collective impulse, are characterised by 
increasingly intense connections between the cultural, social, economic, and physical capitals [60]. Since 2006, built heritage has directly affected the quality of life in the district:

- It strengthens the community, in which citizens associate the context with a shared identity;

- It promotes attachment to the neighbourhood as a place of daily life;

- It stimulates the exchange of knowledge and mental openness;

- It produces a creative stimulus capable of renewing creativity.

The hypothesis that iterative community-led processes can increase sustainability can be validated on a neighbourhood scale, in the Rione Sanità, observing the timing, ways, and procedures activated along ten years:

1. Discovery, raising the community awareness and containing the processes of abandonment and decommissioning up to collect 1500 private donations, 3.5 million $€$ for projects realising 6000 square meters of repurposed built heritage;

2. Negotiation of needs and quality requirements, with the involvement of experts: private and university professionals capable of guiding the choices and accompanying training focused on the constructive specificities of the local heritage;

3. Knowledge and procedures sharing, within the execution and management phases, up to promoting the creation of three social cooperatives capable of intervening on a fragile heritage alongside the inhabitants capable of signalling and identifying failure indicators.

In the case of the Cristallini 73 building, iterativity is a connotative aspect of the repurposing process. The hypothesis that a coevolutionary approach can restore technical awareness, practical ability, and creative intuition to local actors is validated through the observation of the following:

- Timing of the discovery actions, since the end of the physical works in 2015, to the functions and users groups definition (children alongside the elderly);

- How the negotiation is initiated and conducted, with the stipulation of partnerships between the public administration that owns the building, the San Gennaro Community Foundation, two social cooperatives that work on minors at risk, the Ministry of the Interior, the Naples Police Headquarters, and the Fiamme Oro for children's sports introduction 2020;

- The management procedures in using spaces, with the sharing of knowledge and the power of creativity, thanks to the active presence of artists and architects inside the building in continuous dialogue with users, particularly with children.

At the basis of the strategy put in place, it is a pact so that the built heritage can welcome, train, and inspire a neighbourhood in transition. Slowly and implicitly negotiated, through the cooperation between local authorities, entrepreneurship, higher education, and citizens, the pact calls the whole community to commitment; it contributes to redesigning new conditions of use, enhancement, and maintenance from the perspective of shared benefits for built heritage. It funds on the need to transform the occasional and discontinuous community commitment for repurposing into a long-lasting and holistic approach, which is based on the following:

- Mutual trust; the spread of responsible methods of use is accompanied by a direct sensitivity towards the onset of failure conditions, regardless of a third party called upon to perform the role of a manager;

- Opportunity to multiply energies and resources; the repurposing action is refined and enriched in the sharing of procedures and methods, thanks to the comparison between different theoretical and operational knowledge;

- Peer to peer relationship; citizens can choose the most appropriate uses, interacting with managers, technicians, and maintenance experts.

The case study Cristallini 73, with the long duration of the repurposing process and the cyclical iterativity between the phases of built heritage knowledge, scheduling, 
designing, and realisation, outlines some key challenges of community engagement, which are attributable to the following:

(A) Collaborative networks between citizens, companies, volunteering, Third Sector, and privileged actors' cultural intermediation. The community-centred approach holds together various management forms through research and sustaining partnerships. With an initial push from the bottom, the heritage-led and user-driven activities at the Sanità concern all the sectors from culture to arts and crafts, design, and sports. The involvement embraces all social groups inside and outside the neighbourhood and holds several generations together. The community home welcomes those educational and sports activities, which had been started in the Basilica of Santa Maria alla Sanità since 2018. Foundations, associations, and training academies work together, recognising concrete opportunities for redemption, growth, and socialisation in culture, sport, and training. Preserving heritage here means seeking a regulation of transformations which, in the awareness of the uniqueness of each testimony and its multiple documentary characters, maximises permanence, adds its mark, and reinterprets without destroying. The memory emerging from the context loses the value of a mere sign to be revealed or displayed as a cultured quotation in the project; the living matter becomes a generative system capable of producing significant impacts in the present and future [61].

(B) Inclusive dynamics of built heritage care and long-life learning, with the destination of a whole building to host fragile generations. As a place of encounter between children and the elderly, Cristallini 73 is a garrison of legality and exchange of experiences between often distant worlds. Compatibility to repurposing, values preservation, exploiting the inherited material and immaterial resources, and resource optimisation draws incremental processes that enter the practice of inhabitants and operators [62]. Therefore, quality is recognised as a long-term investment, whose overall costs and benefits must be considered equal with the financial value [55]. Education and sport can represent for young generations of the Rione Sanità an alternative to the street, violence, and bullying in a neighbourhood with a high concentration of criminals and early school leaving, and an opportunity to spread the rules respect. This experience testifies to the educational and redemption force of the implemented actions. The engagement is taken over or supplemented by top-down initiatives [63], with expert knowledge supporting the stakeholders' training. The boundary between users and producers of culture tends to become increasingly blurred. The neighbourhood inhabitants are not simply exposed to cultural experiences but understand the rules that generate them. They are expected to acquire the source code underlying the generation of cultural meanings.

(C) Creation of cultural and creative industries also positioned in markets outside the neighbourhood. The opening up to foreign artists and artisans transforms the creative and occasional momentum into a production that looks to the world, giving rise to cultural and creative industries also positioned outside the neighbourhood [62]. A constellation of small artistic and creative enterprises cooperate in the Cristallini 73 management:

- La paranza, a cooperative that won a tender from the Foundation for the South and, thanks to financial support (368,000 euros), made the ancient early Christian basilica of San Gennaro Extra Moenia the gateway to the catacombs for tourists;

- Iron Angels, a cooperative of three artist blacksmiths born as a spin-off of a project of teaching the art of iron aimed at the children of the neighbourhood;

- The Officina dei Talenti, a cooperative made up of technicians and electricians who take care of the maintenance of the spaces in the catacombs;

- The Altra Napoli Onlus, an association founded in 2005 by a small group of friends from Naples but residing elsewhere, who do not resign themselves to passively witnessing the constant decline of the city. In 2006, the foundation's commitment was part of the projects of the Clinton Global Initiative, the Bill and Hillary Clinton Foundation that promotes philanthropic and development activities around the world. In 10 years, the non-profit organisation has contributed to redeeming the district from decay thanks to a commitment to fundraising. 
In light of the sustainable development principles for the Millennium [64], community engagement emerges here as a process of hybridisation between identity and creativity. Two artistic projects hosted in Cristallini 73 intervene on the structural assets of the PNRR: the fight against inequalities, the job placement of young people in situations of fragility, the regeneration of urban assets in marginalised contexts, and the enhancement of the contribution of the Third Sector to society and the development of the South. Attracting creatives from global production contexts opens the community to an international dialogue. The future of built heritage is designed through shared choices that take into account international trends, with continuity and awareness able to interrupt the exclusivity and isolation conditions that long characterised assets. Multiple visions and interests cross heritage priorities. In Cristallini 73, local authorities, entrepreneurship, higher education, and citizens participate in a coevolutionary process where each stakeholder motivates and strengthens the other [65]. Heritage emerges as an open and responsive system in which many actors-as subsystems - act in parallel and in unforeseen, non-linear, and spontaneous ways due to changing circumstances.

Keeping together places and communities, design for repurposing contributes to transmitting tangible and intangible inheritances. The promotion of skills and capabilities gives place to new jobs. Active participation solicits the creativity of individuals; symbiotic relations between built heritage and communities fertilise other sectors of society [24]. Through individual growth, collective creativity is produced, which is capable of affecting the resilience of urban systems and strengthening the local capacity for sustainable development [29]. Paraphrasing the words of Malreaux (1959), the experience carried out demonstrates that built heritage is not inherited but must be conquered.

At the same time, Cristallini 73 is only one piece of a much broader process that restores visibility to a site, thanks to the resonance on social media for the tourist attractiveness of the catacombs and the artist's presence Jago. Other initiatives help to open the community to international dialogue: the book Nostalgia, written by Ermanno Rea in 2016; the docufilm Rione Sanità, the certainty of dreams, written by Conchita Sannino and Massimo Ferrari and presented at the Turin Film festival in 2020, the film The Sanità System, the rejected stones by Mario Pistolese, Andrea De Rosa, shown on Sky in 2021; the movie of Mario Martone based on the book Nostalgia scheduled for spring 2022.

Widening the range of stakeholders with different skills and points of view, the community pool resources, seeking innovative approaches, and establishing effective networks. In addition to the already outlined key challenges, others emerge from the baseline review:

- The development of rules for collaborative networks between local authorities, entrepreneurship, higher education, volunteering, the Third Sector, and experts;

- The promotion of shared approaches for integrating heritage buildings and assets into contemporary life;

- Policies for feeding the communities' creative agency able of renewing the broken threads between the built heritage, cultural resources, and the natural ecosystem;

- The development of innovative functional and technological solutions appropriate to heritage buildings and sites;

- Training processes for a specification and diversification of skills;

- Opening to foreign markets.

\section{Conclusions}

This paper aimed to outline the enabling processes that mark the community engagements in design for repurposing, renewing the symbiosis between the material and immaterial dimensions of heritage. With the support of an international background, built heritage emerges in several experiences: (a) as a linking capital between community and context; (b) an enabler of community engagement and empowerment; (c) the driving force for growth. 
A best practices analysis supports the definition of design for repurposing as a process aimed at the sustainability of assets, based on the rapprochement of people and contexts. Communities' engagement processes are characterised by the coexistence of global strategies that promote spillover effects on contexts: dialogue and collective memory sharing; productivity returned to the built heritage; material culture hybridised with technological innovation; and contemporary art engaged with built heritage. Knowledge implementation, embedded values identification, shared decisions based on functional and technological compatibility, and planning are the local dynamics typical of a community-led cultural and creative engagement. The observation of several best practices realised highlights the following commonalities within repurposing processes: (1) discovering, (2) negotiating, and (3) sharing.

The analysis of the experiences realised in the Sanità district of Naples identifies in a collective pact for built heritage care the frontier of a community engagement based on cooperation between local authorities, entrepreneurship, higher education, and citizens. The transition from occasional and discontinuous stakeholders' involvement to replicable repurposing processes is the novelty of this paper. Supported by the ISO 37104: 2019 [31] and UNI 11151-1: 2005 [32] standards, the case study demonstrates, through the observation of discovery times and actions, negotiation methods and sharing procedures, that the transferability of a coevolutionary engagement can be traced back to the connections promoted between cultural, social, economic, and physical capitals.

The Cristallini 73 case prefigures the following emerging challenges in the repurposing process: (A) activation of collaborative networks; (B) promotion of inclusive dynamics of built heritage care and long-life learning; and (C) creation of cultural and creative industries.

By reactivating the creative agency of communities, built heritage becomes an intermediary of a past identity that comes to life in the present through architectural design. Moreover, the pact gives an operational response to the complexities of public and private relationships. In defining new conditions of use and enhancement for built heritage, the community extracts economic value and social benefits from spaces and culture; through the commitment for sustainability, people become the responsible custodians of embedded values.

Funding: This research was funded by the University of Naples Federico II "Playgrounds and Art for Communities in Transition: care pact for cities" (Call FRA Federico II, 2021-2023). The research is funded by $40,000.00 €$.

Institutional Review Board Statement: Not applicable.

Informed Consent Statement: Not applicable.

Conflicts of Interest: The author declares no conflict of interest. The funders had no role in the design of the study; in the collection, analyses, or interpretation of data; in the writing of the manuscript, or in the decision to publish the results.

\section{References}

1. Potts, A. European Cultural Heritage Green Paper. Europa Nostra, The Hague \& Brussels. Available online: https: / issuu.com/ europanostra/docs/20210322-european_cultural_heritage_green_paper_fu (accessed on 10 February 2022).

2. Grin, J.; Rotmans, J.; Schot, J. Transitions to Sustainable Development, New Directions in the Study of Long Term Transformative Change; Routledge: New York, NY, USA, 2010.

3. Architecs' Council of Europe. Leeuwarden Declaration, Adaptive Reuse and Transition of the Built Heritage. Available online: https://www.ace-cae.eu/fileadmin/New_Upload/_15_EU_Project/Creative_Europe/Conference_Built_Heritage/ LEEUWARDEN_STATEMENT_FINAL_EN-NEW.pdf (accessed on 30 August 2021).

4. Griffiths, R. Cultural strategies and new modes of urban intervention. Cities 1995, 12, 253-265. [CrossRef]

5. Shen, L.Y.; Langston, C. Adaptive reuse potential: An examination of differences between urban and non-urban projects. Facilities 2010, 28, 6-16. [CrossRef]

6. Comunian, R.; Chapain, C.; Clifton, N. Location, location, location: Exploring the complex relationship between creative industries and place. Creative Ind. J. 2010, 3, 5-10. [CrossRef]

7. Pinto, M.R.; Viola, S. Material culture and design effort for the recovery: Living Lab in the Park of Cilento. TECHNE J. Technol. Archit. Environ. 2016, 12, 223-229. 
8. UNESCO. Recommendation on the Historic Urban Landscape. Available online: https://whc.unesco.org/uploads/activities/ documents/activity-638-98.pdf (accessed on 21 March 2019).

9. The Council of Europe Secretariat in Consultation with the Faro Convention Network (FCN) Members. The Faro Convention Action Plan Handbook for 2018-2019. Available online: https://www.coe.int/en/web/culture-and-heritage/faro-action-plan (accessed on 21 March 2019).

10. European Union. Built Cultural Heritage Integrating Heritage Buildings into Contemporary Society. Available online: https: / / www.interregeurope.eu/fileadmin/user_upload/plp_uploads/policy_briefs/Policy_brief_on_built_cultural_heritage.pdf (accessed on 1 December 2021).

11. Babelon, J.P.; Chastel, A. La notion de patrimoine. In Revue de l'Art; Editions Ophrys: Paris, France, 1980; Volume 49, pp. 5-32.

12. UNESCO. Convention Concerning the Protection of the World Cultural and Natural Heritage. Available online: http://whc. unesco.org/en/conventiontext (accessed on 30 August 2021).

13. UNESCO. Revision of the Operational Guidelines for the Implementation of the World Heritage Convention: Report of the Expert Group on Cultural Landscapes. Available online: http://whc.unesco.org/archive/pierre92.htm (accessed on 30 August 2021).

14. Vecco, M. L'Evoluzione del Concetto di Patrimonio Culturale, 2nd ed.; Franco Angeli: Milano, Italy, 2011.

15. TUE. Treaty on European Union. Off. J. Eur. Communities 1992. Available online: https://eur-lex.europa.eu/eli/treaty/teu/sign (accessed on 30 August 2021).

16. TFUE. Consolidated Version of the Treaty on the Functioning of the European Union. Off. J. Eur. Union C 2012. Available online: https:/ / eur-lex.europa.eu/eli/treaty/tfeu_2012/oj (accessed on 30 August 2021).

17. European Parliament. Official Journal of the European Union, c83, Volume $53^{\circ}$ Year 30 Marzo, 2010/C 83. Available online: https:/ / eur-lex.europa.eu/legal-content/IT/TXT/PDF/?uri=OJ:C:2010:083:FULL\&from=GA (accessed on 30 August 2021).

18. Ball, R. Reuse potential and vacant industrial premises: Revisiting the regeneration issue in stoke-on-trent. J. Prop. Res. 2002, 19, 93-110. [CrossRef]

19. Caterina, G. Innovative strategies for the recovering of historical cities. TECHNE J. Technol. Archit. Environ. 2016, 12, 33-35.

20. Council of the European Union. Council Conclusions on Participatory Governance of Cultural Heritage 2014/C 463/01. Available online: https:/ / eur-lex.europa.eu/legal-content/EN/TXT/PDF/?uri=CELEX:52014XG1223(01)\&from=EN (accessed on 30 August 2021).

21. Veldpaus, L.; Pereira Roders, A.R. The historic urban landscape: Learning from a Legacy. In Proceedings of the 4th International Conference on Heritage and Sustainable Development, Guimaraes, Portugal, 22-25 July 2014; pp. $129-141$.

22. Council of the European Union. Conclusions Establishing a Work Plan for Culture (2015-2018). Available online: https: / / data.consilium.europa.eu/doc/document/ST-16094-2014-INIT/en/pdf (accessed on 30 August 2021).

23. European Commission. European Framework for Action on Cultural Heritage; SWD (2018) 491 Final. Available online: http:/ / www.historic-towns.org/wp-content/uploads/2019/01/EU-Framework-for-Action-on-Cultural-Heritage.pdf (accessed on 30 August 2021).

24. Rosetti, I.; Bertrand Cabral, C.; Pereira Roders, A.; Jacobs, M.; Albuquerque, R. Heritage and Sustainability: Regulating Participation. Sustainability 2022, 14, 1674. [CrossRef]

25. European Commission. Getting Cultural Heritage to Work for Europe. Report of the Horizon 2020 Expert Group on Cultural Heritage. Available online: https:/ / op.europa.eu/en/publication-detail/-/publication/b01a0d0a-2a4f-4de0-88f7-85bf2dc6e004 (accessed on 30 August 2021).

26. Vandersande, A.; Van Balen, K.; Thys, C.; Van der Auwera, S.; Verpoest, L.; Jagodzinska, K.; Sanetra-Szeliga, J.; Purchla, J. Cultural Heritage Counts for Europe; Krakow Press: Krakow, Poland, 2015.

27. Council of Europe. European Cultural Heritage Strategy for the 21st Century. Available online: https://www.coe.int/en/web/ culture-and-heritage/strategy-21 (accessed on 30 August 2021).

28. Working Group of Member States' Experts. Participatory Governance of Cultural Heritage. The Open Method of Coordination (OMC). Available online: https:/ / op.europa.eu/en/publication-detail/-/publication/b8837a15-437c-11e8-a9f4-01aa75ed71a1 /language-en (accessed on 30 August 2021).

29. van Knippenberg, K.; Boonstra, B.; Boelens, L. Communities, Heritage and Planning: Towards a Co-Evolutionary Heritage Approach. Plan. Theory Pract. 2021. [CrossRef]

30. Vecco, M. A definition of cultural heritage: From the tangible to the intangible. J. Cult. Herit. 2010, 11, 321-324. [CrossRef]

31. ISO 37104:2019; Sustainable Cities and Communities-Transforming Our Cities-Guidance for Practical Local Implementation of ISO 37101. Technical Committee ISO 268. International Organization for Standardization: Vernier, Switzerland, 2019.

32. UNI 11151:2005; Processo Edilizio-Definizione delle Fasi Processuali per Gli Interventi sul Costruito. Technical Committee Prodotti, processi e sistemi per l'organismo Edilizio. Ente Nazionale Italiano di Unificazione: Milan, Italy, 2005.

33. Lowenthal, D. The Past is a Foreign Country; Cambridge University Press: Cambridge, UK, 1985.

34. Samuel, R. Theatres of Memory; Verso Books: London, UK, 1994.

35. Ashworth, G. Paradigms and paradoxes in planning the past. In Selling or Telling? Paradoxes in Tourism, Culture and Heritage; Smith, M., Onderwater, L., Eds.; Association for Tourism and Leisure Education: Arnhem, The Netherlands, 2008.

36. Graham, B.; Ashworth, G.; Tunbridge, J. A Geography of Heritage: Power, Culture, and Economy; Oxford University Press: Oxford, UK, 2000. 
37. Harrison, R. Forgetting to remember, remembering to forget: Late modern heritage practices, sustainability and the 'crisis' of accumulation of the past. Int. J. Herit. Stud. 2013, 19, 579-595. [CrossRef]

38. Macdonald, S. Memorylands: Heritage and Identity in Europe Today; Routledge: New York, NY, USA, 2013.

39. Perkin, C. Beyond the rhetoric: Negotiating the politics and realising the potential of community-driven heritage engagement. Int. J. Herit. Stud. 2010, 16, 107-122. [CrossRef]

40. Achig-Balarezo, M.C.; Vázquez, L.; Barsallo, M.G.; Briones, J.C.; Amaya, J. Strategies for the management of built heritage linked to maintenance and monitoring. Case study of the San Roque Neighborhood, Cuenca, Ecuador. Int. Arch. Photogramm. Remote Sens. Spatial Inf. Sci. 2017, XLII-2/W5, 755-761. Available online: https://pdfs.semanticscholar.org/f671/09f220a74fc61a77f90b8a5 141ed4b9d4658.pdf (accessed on 15 January 2022). [CrossRef]

41. De Leiuen, C.; Arthure, S. Collaboration on whose terms? Using the IAP2 community engagement model for archaeology in Kapunda, South Australia. J. Community Archaeol. Herit. 2016, 3, 81-98. [CrossRef]

42. Boonstra, B. Planning Strategies in an Age of Active Citizenship: A Post-Structuralist Agenda for Self-Organisation in Spatial Planning. Ph.D. Thesis, University of Utrecht, Utrecht, The Netherlands, 2015.

43. Poulios, I. Discussing strategy in heritage conservation: Living heritage approach as an example of strategic innovation. J. Cult. Herit. Manag. Sustain. Dev. 2014, 4, 16-34. [CrossRef]

44. Ferretti, V.; Gandino, E. Co-designing the solution space for rural regeneration in a new World Heritage site: A choice experiments approach. Eur. J. Oper. Res. 2018, 268, 1077-1091. [CrossRef]

45. Li, J.; Krishnamurthy, S.; Pereira Roders, A.; van Wesemael, P. Community participation in cultural heritage management: A systematic literature review comparing Chinese and international practices. Cities 2020, 96, 102476. [CrossRef]

46. KEA. Successful Investments in Culture in European Cities and Regions: A Catalogue of Case Studies. Available online: https:/ / keanet.eu/projects/culture-for-cities-and-regions / (accessed on 10 February 2022).

47. Curtis, M. Temple Bar: A history; The History Press Ireland: Dublin, Ireland, 2016.

48. Ochoa, R. The "Expo" and the Post-“Expo": The Role of Public Art in Urban Regeneration Processes in the Late 20th Century. Sustainability 2022, 14, 985. [CrossRef]

49. KEA \& PPMI. Research for CULT Committee-Culture and Creative Sectors in the European Union Key Future Developments, Challenges and Opportunities, European Parliament, Policy Department for Structural and Cohesion Policies, Brussels. 2019. Available online: http://www.europarl.europa.eu/RegData/etudes/STUD/2019/629203/IPOL_STU(2019)629203_EN.pdf (accessed on 10 February 2022).

50. Sciacchitano, E. Editorial: European year of Cultural-Heritage. A laboratory for heritage-based innovation. Sci. Res. Inf. Technol. 2019, 9, 1-14.

51. Pinto, M.R.; Viola, S.; Onesti, A.; Ciampa, F. Artists Residencies, Challenges and Opportunities for Communities' Empowerment and Heritage Regeneration. Sustainability 2020, 12, 9651. [CrossRef]

52. Cooke, P.; Lazzeretti, L. Creative Cities, Cultural Clusters and Local Economic Development; Edward Elgar Publishing: Cheltenham, UK, 2008.

53. Wilkinson, S.J.; James, K.; Reed, R. Using building adaptation to deliver sustainability in Australia. Struct. Surv. 2009, $27,46-61$. [CrossRef]

54. Council of Europe. A New Strategic Agenda 2019-2024. Available online: https://www.consilium.europa.eu/media/39914/anew-strategic-agenda-2019-2024.pdf (accessed on 10 February 2022).

55. ICOMOS. European Quality Principles for EU-Funded Interventions with Potential Impact upon Cultural Heritage; ICOMOS: Paris, France, 2020.

56. Cornell Empowerment Group. Networking ... Bulletin Empowerment \& Family Support; Cornell Empowerment Group: Ithaca, NY, USA, 1989

57. Salomone, C. Patrimoine et Valorisation Touristique au Cœur D'une Tentative de Requalification D'un Quartier: Le Cas de la Sanità à Naples, 50e Colloque ASRDLF, Culture, Patrimoine et Savoirs, Mons 8-11 Juillet, 2013. Available online: http: //www.asrdlf2013.org/spipb0c8.php?rubrique11 (accessed on 10 February 2022).

58. De Seta, C.; Forte, B. Santa Maria della Sanità. The Form and Splendour of Beauty; Edizioni San Gennaro: Napoli, Italy, 2020.

59. Salomone, C. La Naples souterraine et le tourisme de l'insolite où comment réinventer une destination touristique traditionnelle? Téoros 2016, 34, 1-2.

60. Rodwell, D. Conservation and Sustainability in Historic Cities; Blackwell Publishing: Oxford, UK, 2007.

61. Bellini, A. A Proposito di Alcuni Equivoci Sulla Conservazione; TeMa: Milano, Italy, 1996.

62. Viola, S.; Zain, U.A. Cultural and Creative Industries. Technological Innovation for the Built Environment; La Scuola di Pitagora: Napoli, Italy, 2021.

63. Sacco, P.L.; Ferilli, G.; Tavano Blessi, G.; Nuccio, M. Culture as an engine of local development processes: System-Wide Cultural Districts. II: Prototype cases. Growth Change 2013, 44, 571-588. [CrossRef]

64. United Nations. Transforming Our World: The 2030 Agenda for Sustainable Development. Resolution Adopted by the General Assembly on 25 September 2015. Available online: https://www.un.org/ga/search/view_doc.asp?symbol=A/RES/70/1\&Lang= E (accessed on 30 August 2021).

65. Caliandro, C.; Sacco, P.L. Italia Reloaded. Ripartire con la Cultura; Società Editrice il Mulino: Bologna, Italy, 2011. 